\title{
PERKEMBANGAN PENELITIAN MENGENAI PERGANTIAN AUDITOR
}

\author{
Abdurrahman Zaki Mustofa \\ Universitas Sebelas Maret \\ Zaki_mustofa@yahoo.co.id
}

\begin{abstract}
This study aims to provide an overview of the development of the research related to audit switch, the samples taken from various national journal that can be accessed online. 18 samples taken from 9 national journals with the time span of 2009 to 2018. This research use Charting the Field method that was developed by Hesford et al (2007) where the researcher classified articles based on the topic and research method that is used on the articles. The results show that the most researched variable is Pergantian Manajemen. Research topic related to audit switch that is researched the most is anteseden topic, using Pergantian Manajemen Variable. The research method that is used the most is analytic method and among all samples there is no article that use review method.
\end{abstract}

Keywords: Analytic Method, Audit Switch, Bibliography, Charting the Field, Management Switch

\section{PENDAHULUAN}

Audit adalah suatu proses sistematik yang bertujuan untuk mengevaluasi bukti yang dikumpulkan atas pernyataan atau asersi mengenai berbagai aksi ekonomi, kejadian-kejadian dan melihat tingkat hubungan antara pernyataan atau asersi dengan kenyataan, serta mengomunikasikan hasilnya kepada yang berkepentingan. Auditor yang memiliki kredibilitas, selain dapat mendeteksi adanya penyajian kesalahan yang material, dapat juga memberikan nasihat kepada klien mereka terkait kelangsungan usahanya. Banyak negara yang memiliki aturan terkait pergantian auditor, karena audit tenure yang terlalu panjang dapat meningkatkan risiko fraud dalam perusahaan. Pergantian auditor memiliki berbagai penyebab serta dampak bagi perusahaan dan auditor itu sendiri. Hal ini lah yang membuat banyak peneliti tertarik untuk meneliti berbagai hal yang terkait dengan pergantian auditor, baik penyebab pergantian, pertimbangan memilih auditor, serta dampak-dampak yang timbul dari pergantian yang dilakukan.

Penelitian ini memiliki tujuan untuk melihat perkembangan penelitian yang terkait dengan pergantian auditor. Peneliti mencoba mengaji 18 artikel yang dipublikasikan di jurnal nasional dengan metode "Charting the Field" dan "Analyzing the Community" untuk memetakan perkembangan penelitian mengenai pergantian auditor sejak tahun 2009 sampai 2018.

Kontribusi dari penelitian ini adalah pertama, memberikan analisa terhadap penelitian mengenai pergantian auditor yang dipublikasikan di berbagai jurnal internasional, penelitian ini dapat dijadikan bahan acuan apabila terdapat peneliti lain yang ingin melakukan penelitian terkait pergantian auditor. Kedua, penelitian ini dapat membantu memberikan gambaran mengenai topik penelitian yang dapat dikembangkan terkait dengan pergantian auditor.

\section{METODE PENELITIAN}

Metode yang digunakan dalam penelitian ini adalah metode "Charting the Field" yang dikembangkan oleh Hesford dkk. (2007). Dalam pendekatan ini, peneliti mencoba memilih beberapa artikel penelitian tentang pergantian auditor dan sejenisnya yang diterbitkan di berbagai jurnal nasional, kemudian dikelompokkan berdasarkan topik, metode penelitian dan 
disiplin ilmu. Pemilihan jurnal-jurnal disesuaikan dengan kriteria: pertama, jurnal yang ter akreditasi pada tahun 2019. Kedua, jurnal dapat diakses secara online. Peneliti mencari dan memilih secara terstruktur artikel di berbagai situs penerbit jurnal nasional dan memasukkan artikel-artikel yang dapat diakses. Ketiga, hanya memilih artikel yang terkait dengan pergantian auditor.

\section{Tabel 1}

Daftar Artikel

No Nama Jurnal Universitas Judul Artikel

Penulis Tahun Level

Jurnal

\begin{tabular}{|c|c|c|c|c|c|c|}
\hline 1 & $\begin{array}{l}\text { Jurnal } \\
\text { Dinamika } \\
\text { Akuntansi }\end{array}$ & $\begin{array}{l}\text { Universitas } \\
\text { Negeri } \\
\text { Semarang }\end{array}$ & $\begin{array}{lr}\text { Faktor-Faktor } & \text { yang } \\
\text { Mempengaruhi } & \text { Pergantian } \\
\text { Auditor: Studi } & \text { Empiris } \\
\text { Perusahaan Publik di Indonesia }\end{array}$ & $\begin{array}{l}\text { Prastiwi, A \& } \\
\text { Wilsya, F }\end{array}$ & 2009 & S2 \\
\hline 2 & $\begin{array}{l}\text { Jurnal } \\
\text { Dinamika } \\
\text { Akuntansi }\end{array}$ & $\begin{array}{l}\text { Universitas } \\
\text { Negeri } \\
\text { Semarang }\end{array}$ & $\begin{array}{l}\text { Faktor-Faktor } \\
\text { Mempengaruhi Yang } \\
\text { Berpindah Keinginan } \\
\text { Empiris pada Kantor Akuntan } \\
\text { Publik di Jawa Tengah dan } \\
\text { Daerah Istimewa Yogyakarta) }\end{array}$ & Permatasari, D & 2013 & S2 \\
\hline 3 & $\begin{array}{l}\text { Jurnal } \\
\text { Dinamika } \\
\text { Akuntansi }\end{array}$ & $\begin{array}{l}\text { Universitas } \\
\text { Negeri } \\
\text { Semarang }\end{array}$ & $\begin{array}{l}\text { Pengaruh Penerbitan Opini } \\
\text { Going Concern pada Pergantian } \\
\text { Auditor pada Perusahaan yang } \\
\text { Terdaftar pada Bursa } \\
\text { Indonesia }\end{array}$ & $\begin{array}{l}\text { Adhiputra, M. } \\
\text { W. }\end{array}$ & 2015 & S2 \\
\hline 4 & $\begin{array}{l}\text { Media Riset } \\
\text { Akuntansi, } \\
\text { Auditing \& } \\
\text { Informasi }\end{array}$ & $\begin{array}{l}\text { Universitas } \\
\text { Trisakti }\end{array}$ & $\begin{array}{l}\text { Pengaruh Financial Distress, } \\
\text { Pergantian Manajemen dan } \\
\text { Ukuran KAP Terhadap Auditor } \\
\text { Switching }\end{array}$ & $\begin{array}{l}\text { Ismanto, J. \& } \\
\text { Manda, D. L., }\end{array}$ & 2018 & S2 \\
\hline 5 & $\begin{array}{l}\text { Jurnal } \\
\text { Akuntansi } \\
\text { Multiparadig } \\
\text { ma }\end{array}$ & $\begin{array}{l}\text { Universitas } \\
\text { Brawijaya }\end{array}$ & $\begin{array}{l}\text { Determinants of Downward } \\
\text { Auditor Switching }\end{array}$ & $\begin{array}{l}\text { Budisantoso, } \\
\text { T., } \\
\text { Rahmawati., } \\
\text { Bandi., } \\
\text { Probohudono, } \\
\text { A. N. }\end{array}$ & 2017 & S2 \\
\hline 6 & $\begin{array}{l}\text { Jurnal } \\
\text { Akuntansi } \\
\text { Multiparadig } \\
\text { ma }\end{array}$ & $\begin{array}{l}\text { Universitas } \\
\text { Brawijaya }\end{array}$ & $\begin{array}{l}\text { "Kamuflase" dalam Praktik } \\
\text { Rotasi Auditor }\end{array}$ & $\begin{array}{l}\text { Irianto, } \quad \text { G., } \\
\text { Novianti, } \\
\text { Wulandari, } \\
\text { P. }\end{array}$ & 2014 & $\mathrm{~S} 2$ \\
\hline 7 & $\begin{array}{l}\text { Jurnal Ilmiah } \\
\text { Akuntansi dan } \\
\text { Bisnis }\end{array}$ & $\begin{array}{l}\text { Universitas } \\
\text { Udayana }\end{array}$ & $\begin{array}{l}\text { Analisis Prediksi Potensi Risiko } \\
\text { Fraudulent Financial Statement } \\
\text { Melalui Personal Financial Need } \\
\text { dan Auditor Switching }\end{array}$ & $\begin{array}{l}\text { Werastuti, D. } \\
\text { N.S. }\end{array}$ & 2015 & $\mathrm{~S} 2$ \\
\hline
\end{tabular}




\begin{tabular}{|c|c|c|c|c|c|c|}
\hline 8 & $\begin{array}{l}\text { Jurnal Ilmiah } \\
\text { Akuntansi dan } \\
\text { Bisnis }\end{array}$ & $\begin{array}{l}\text { Universitas } \\
\text { Udayana }\end{array}$ & $\begin{array}{l}\text { Analisis Pengaruh Opini Audit } \\
\text { Going Concern dan Pergantian } \\
\text { Manajemen Pada Auditor } \\
\text { Switching }\end{array}$ & $\begin{array}{l}\text { Wahyuningsih, } \\
\text { N. \& \& } \\
\text { Suryanawa, I. } \\
\text { K. }\end{array}$ & 2012 & S2 \\
\hline 9 & $\begin{array}{l}\text { Jurnal } \\
\text { Akuntansi dan } \\
\text { Keuangan }\end{array}$ & $\begin{array}{l}\text { Universitas } \\
\text { Kristen Petra }\end{array}$ & $\begin{array}{l}\text { Pengaruh Tenure, Rotasi dan } \\
\text { Spesialisasi Kantor Akuntan } \\
\text { Publik (KAP) Terhadap Kualitas } \\
\text { Audit: Perbandingan Sebelum } \\
\text { dan Sesudah Regulasi Rotasi } \\
\text { KAP di Indonesia }\end{array}$ & $\begin{array}{l}\text { Fitriany, } \\
\text { Utama, S., } \\
\text { Martani, D., } \\
\text { Rosietta, H. }\end{array}$ & 2015 & S2 \\
\hline 10 & $\begin{array}{l}\text { Jurnal } \\
\text { Akuntansi dan } \\
\text { Keuangan } \\
\text { Indonesia }\end{array}$ & $\begin{array}{l}\text { Universitas } \\
\text { Indonesia }\end{array}$ & $\begin{array}{lr}\text { Rotasi dan Kualitas } & \text { Audit: } \\
\text { Evaluasi Atas Kebijakan Menteri } \\
\text { Keuangan KMK } & \text { No. } \\
\text { 423/KMK.6/2002 Tentang } & \text { Jasa } \\
\text { Akuntan Publik } & \end{array}$ & $\begin{array}{l}\text { Siregar, S. V., } \\
\text { Fitriany, } \\
\text { Wibowo, A., } \\
\text { Anggraita, V. }\end{array}$ & 2011 & $\mathrm{~S} 2$ \\
\hline 11 & $\begin{array}{l}\text { Jurnal Reviu } \\
\text { Akuntansi dan } \\
\text { Keuangan }\end{array}$ & $\begin{array}{l}\text { Universitas } \\
\text { Muhammadi } \\
\text { yah Malang }\end{array}$ & $\begin{array}{l}\text { Pengaruh Financial Distress, } \\
\text { Pertumbuhan Perusahaan, } \\
\text { Rentabilitas, Ukuran Kap, dan } \\
\text { Ukuran Perusahaan Terhadap } \\
\text { Pergantian Auditor }\end{array}$ & $\begin{array}{l}\text { Maryani, S., } \\
\text { Respati, N. W., } \\
\text { Safrida, L. }\end{array}$ & 2016 & S3 \\
\hline 12 & $\begin{array}{l}\text { Jurnal Reviu } \\
\text { Akuntansi dan } \\
\text { Keuangan }\end{array}$ & $\begin{array}{l}\text { Universitas } \\
\text { Muhammadi } \\
\text { yah Malang }\end{array}$ & $\begin{array}{l}\text { Pengaruh Masa Perikatan Audit, } \\
\text { Rotasi Audit dan Ukuran Kantor } \\
\text { Akuntan Publik Terhadap } \\
\text { Kualitas Audit }\end{array}$ & $\begin{array}{l}\text { Paputungan, R. } \\
\text { D. \& Kaluge, } \\
\text { D. }\end{array}$ & 2018 & S3 \\
\hline 13 & $\begin{array}{l}\text { Jurnal Reviu } \\
\text { Akuntansi dan } \\
\text { Keuangan }\end{array}$ & $\begin{array}{l}\text { Universitas } \\
\text { Muhammadi } \\
\text { yah Malang }\end{array}$ & $\begin{array}{llr}\text { Pengaruh Opini Going Concern, } \\
\text { Pergantian } & \text { Manajemen } & \text { dan } \\
\text { Ekspansi } & \text { Internal } & \text { Terhadap } \\
\text { Auditor } & \text { Switching } & \text { Secara } \\
\text { Voluntary } & & \\
\end{array}$ & $\begin{array}{l}\text { Karina, F. L., } \\
\text { Kholmi, M., } \\
\text { Harventy, G. }\end{array}$ & 2014 & S3 \\
\hline 14 & $\begin{array}{l}\text { Jurnal } \\
\text { Akuntansi } \\
\text { Akrual }\end{array}$ & $\begin{array}{l}\text { Universitas } \\
\text { Negeri } \\
\text { Malang }\end{array}$ & $\begin{array}{l}\text { Pengaruh Rotasi Kap, Audit } \\
\text { Tenure, dan Reputasi Kap } \\
\text { Terhadap Kualitas Audit Pada } \\
\text { Perusahaan Manufaktur }\end{array}$ & $\begin{array}{ll}\text { Nurhayati, } & \text { S. } \\
\text { \& Prastiti, } & \text { S. } \\
\text { D. } & \end{array}$ & 2015 & S4 \\
\hline
\end{tabular}

\begin{tabular}{lllllll}
\hline 15 & Accounting & Universitas & Analisis Faktor-Faktor yang Aprilia, E. & 2013 & S4 \\
Analysis & Negeri & Mempengaruhi & Auditor & & \\
& Journal & Semarang & Switching & & &
\end{tabular}

\begin{tabular}{llllll}
\hline 16 & Accounting & Universitas & Empirical Study of Public Rokhmatun, R. 2016 & S4 \\
Analysis & Negeri & Accounting Firm Changes on N. \& Suryarini, & & \\
Journal & Semarang & The Company after the T. & \\
& & Emergence of The Public & \\
& Accounting Firm Regulatory & \\
& Liability & \\
\hline
\end{tabular}




\begin{tabular}{|c|c|c|c|c|c|c|}
\hline 17 & $\begin{array}{l}\text { Accounting } \\
\text { Analysis } \\
\text { Journal }\end{array}$ & $\begin{array}{l}\text { Universitas } \\
\text { Negeri } \\
\text { Semarang }\end{array}$ & $\begin{array}{l}\text { The Determinant of KAP } \\
\text { Changes with Audit Committee } \\
\text { Quality as A Moderating } \\
\text { Variable }\end{array}$ & $\begin{array}{l}\text { Fadil, Y. \& } \\
\text { Yulianto, A. }\end{array}$ & 2017 & S4 \\
\hline 18 & $\begin{array}{l}\text { Accounting } \\
\text { Analysis } \\
\text { Journal }\end{array}$ & $\begin{array}{l}\text { Universitas } \\
\text { Negeri } \\
\text { Semarang }\end{array}$ & $\begin{array}{l}\text { Analysis of The Influence of The } \\
\text { Size of KAP, Management } \\
\text { Turnover and Size of Company } \\
\text { Toward Auditor Switching (An } \\
\text { Empirical Study On onpanies } \\
\text { Manufacturing Stock } \\
\text { Registered in Indonesian Sto } \\
\text { Exchange Year 2011-2015) }\end{array}$ & $\begin{array}{l}\text { Nurcahyo, D. } \\
\text { D. \& } \\
\text { Anisykurlillah, } \\
\text { I. }\end{array}$ & 2018 & S4 \\
\hline
\end{tabular}

\section{Hasil}

Penelitian ini menggunakan 18 artikel yang diperoleh dari 9 jurnal nasional yang telah memenuhi kriteria. Judul artikel dan penulis telah disajikan pada Tabel 1 .
Tahun 2009 dijadikan tahun pertama dengan pertimbangan pada tahun tersebut diterbitkan artikel paling awal yang membahas pergantian auditor di jurnaljurnal nasional.

Tabel 2

Deskripsi Sampel

\begin{tabular}{|c|c|c|c|c|c|c|c|}
\hline \multirow[t]{2}{*}{ No } & \multirow[t]{2}{*}{ Nama Jurnal } & \multicolumn{2}{|c|}{2009 s/d 2018} & \multicolumn{2}{|c|}{2009 s/d 2013} & \multicolumn{2}{|c|}{2014 s/d 2018} \\
\hline & & Jumlah & Persentase & Jumlah & Persentase & Jumlah & Persentase \\
\hline 1 & Jurnal Dinamika Akuntansi & 3 & $17 \%$ & 2 & $40 \%$ & 1 & $8 \%$ \\
\hline 2 & $\begin{array}{l}\text { Media Riset Akuntansi, Auditing \& } \\
\text { Informasi }\end{array}$ & 1 & $6 \%$ & 0 & $0 \%$ & 1 & $8 \%$ \\
\hline 3 & Jurnal Akuntansi Multiparadigma & 2 & $11 \%$ & 0 & $0 \%$ & 2 & $15 \%$ \\
\hline 4 & Jurnal Ilmiah Akuntansi dan Bisnis & 2 & $11 \%$ & 1 & $20 \%$ & 1 & $8 \%$ \\
\hline 5 & Jurnal Akuntansi dan Keuangan & 1 & $6 \%$ & 0 & $0 \%$ & 1 & $8 \%$ \\
\hline 6 & $\begin{array}{l}\text { Jurnal Akuntansi dan Keuangan } \\
\text { Indonesia }\end{array}$ & 1 & $6 \%$ & 1 & $20 \%$ & 0 & $0 \%$ \\
\hline 7 & Jurnal Reviu Akuntansi dan Keuangan & 3 & $17 \%$ & 0 & $0 \%$ & 3 & $23 \%$ \\
\hline 8 & Jurnal Akuntansi Akrual & 1 & $6 \%$ & 0 & $0 \%$ & 1 & $8 \%$ \\
\hline 9 & Accounting Analysis Journal & 4 & $22 \%$ & 1 & $20 \%$ & 3 & $23 \%$ \\
\hline & TOTAL & 18 & & 5 & & 13 & \\
\hline
\end{tabular}

Tabel 2 menunjukkan jurnal-jurnal yang digunakan dalam penelitian ini, dibagi menjadi 2 periode yaitu 2009-2013 dan 2014-2018. Kebanyakan jurnal hanya memiliki 1 artikel terkait pergantian auditor, sementara terdapat beberapa jurnal yang memiliki artikel relatif lebih banyak dari jurnal lain. Jurnal Accounting Analysis Journal memiliki 4 artikel yang terkait dengan pergantian auditor $(22 \%$ dari keseluruhan data), diikuti Jurnal Dinamika
Akuntansi dan Jurnal Reviu Akuntansi Keuangan yang memiliki 3 artikel terkait pergantian auditor (17\% dari keseluruhan data).

Berdasarkan data diatas, penelitian terkait pergantian auditor mengalami peningkatan yang signifikan pada periode 2014-2018, dimana pada periode tersebut terdapat 13 artikel yang membahas mengenai pergantian auditor, jauh lebih 
banyak dari periode 2009-2013 yang hanya memiliki 5 artikel terkait pergantian auditor.

\section{HASIL DAN PEMBAHASAN \\ Klasifikasi Artikel}

Pada penelitian ini setiap artikel dikelompokkan pada dua klasifikasi yaitu topik dan metode penelitian dengan mengacu kepada penelitian Hesford dkk (2007).

\section{Klasifikasi berdasarkan Topik Pembahasan}

Pengklasifikasian artikel tentang pergantian auditor berdasarkan pada topik penelitian dibedakan menjadi 2 yaitu anteseden (faktor-faktor yang memotivasi terjadinya pergantian auditor) dan konsekuensi (pengaruh dari pergantian auditor). Tabel 3 menunjukkan klasifikasi artikel mengenai pergantian auditor berdasarkan topik. Dalam tabel tersebut ditunjukkan bahwa $67 \%$ penelitian (12 artikel) meneliti mengenai anteseden dari pergantian auditor, $28 \%$ penelitian (5 artikel) meneliti mengenai konsekuensi pergantian auditor, 6\% (1 artikel) meneliti mengenai anteseden dan konsekuensi dari pergantian auditor.

Jika dibandingkan antara periode pertama dan kedua, secara umum setiap topik mengalami kenaikan pada periode kedua. Topik anteseden mengalami kenaikan yang signifikan, topik anteseden pada periode kedua naik lebih dari 2 kali lipat dibandingkan periode pertama, tidak terdapat artikel yang membahas mengenai topik konsekuensi pada periode pertama namun terdapat 5 artikel yang membahas topik tersebut di periode kedua, sementara topik anteseden dan konsekuensi mengalami penurunan dari 1 artikel menjadi 0 artikel di periode kedua.

Tabel 3

Klasifikasi Artikel berdasarkan Topik

\begin{tabular}{|c|c|c|c|c|c|c|c|c|}
\hline \multirow[t]{2}{*}{ No } & \multirow[t]{2}{*}{ Topik } & & \multicolumn{2}{|c|}{2009 s/d 2018} & \multicolumn{2}{|c|}{2009 s/d 2013} & \multicolumn{2}{|c|}{2013 s/d 2018} \\
\hline & & & Jumlah & Persentase & Jumlah & Persentase & Jumlah & Persentase \\
\hline 1 & Anteseden & & 12 & $67 \%$ & 4 & $80 \%$ & 8 & $62 \%$ \\
\hline 2 & Konsekuensi & & 5 & $28 \%$ & 0 & $0 \%$ & 5 & $38 \%$ \\
\hline 3 & $\begin{array}{l}\text { Anteseden } \\
\text { Konsekuensi }\end{array}$ & $\&$ & 1 & $6 \%$ & 1 & $20 \%$ & 0 & $0 \%$ \\
\hline & & & 18 & & 5 & & 13 & \\
\hline
\end{tabular}

Tabel 4

Klasifikasi Variabel Anteseden

\begin{tabular}{llll}
\hline No & Variabel & Jumlah & Persentase \\
\hline $\mathbf{1}$ & Ambiguitas Peran Manajemen & 1 & $2 \%$ \\
\hline $\mathbf{2}$ & Financial Deepening & 1 & $2 \%$ \\
\hline $\mathbf{3}$ & Financial Distress & 5 & $12 \%$ \\
\hline $\mathbf{4}$ & Financial statement & 1 & $2 \%$ \\
\hline $\mathbf{5}$ & Foreign Ownership & 1 & $2 \%$ \\
\hline $\mathbf{6}$ & Gaya Kepemimpinan & 1 & $2 \%$ \\
\hline $\mathbf{8}$ & Institutional Ownership & 1 & $2 \%$ \\
\hline $\mathbf{9}$ & Kebutuhan Untuk Berkembang & 1 & $2 \%$ \\
\hline $\mathbf{1 0}$ & Kepemilikan Publik & 1 & $2 \%$ \\
\hline $\mathbf{1 1}$ & Kesempan Gaji & 1 & $2 \%$ \\
\hline $\mathbf{1 0}$ & & 1 & $2 \%$ \\
\hline
\end{tabular}

107 DAMPAK INFORMASI SOSIAL DAN LINGKUNGAN TERHADAP KEPUTUSAN MANAJER 


\begin{tabular}{|c|c|c|c|}
\hline 12 & Ketepatwaktuan Pelaporan Keuangan & 1 & $2 \%$ \\
\hline 13 & Komite Audit & 1 & $2 \%$ \\
\hline 14 & Konflik Peran & 1 & $2 \%$ \\
\hline 15 & Managerial Ownership & 1 & $2 \%$ \\
\hline 16 & Opini audit & 3 & $7 \%$ \\
\hline 17 & Opini Going Concern & 1 & $2 \%$ \\
\hline 18 & Pergantian Manajemen & 6 & $14 \%$ \\
\hline 19 & Personal financial need & 1 & $2 \%$ \\
\hline 20 & Pertumbuhan Perusahaan & 2 & $5 \%$ \\
\hline 21 & Perubahan Pendapatan Perusahaan & 1 & $2 \%$ \\
\hline 22 & Profitabilitas & 1 & $2 \%$ \\
\hline 23 & Rentabilitas & 1 & $2 \%$ \\
\hline 24 & Ukuran Auditor & 3 & $7 \%$ \\
\hline \multirow[t]{2}{*}{25} & Ukuran Perusahaan & 5 & $12 \%$ \\
\hline & & 43 & \\
\hline
\end{tabular}

Tabel 4 menjelaskan tentang variabel yang dipakai pada artikel dengan topik anteseden yang dibahas oleh meneliti. Dari 18 artikel, variable pergantian manajemen menjadi variabel yang paling banyak diteliti yaitu sebanyak 6 artikel atau sebesar $14 \%$. Variabel lain seperti financial distress dan ukuran perusahaan memiliki jumlah 5 artikel atau sebesar $12 \%$, variabel opini audit dan ukuran auditor dibahas oleh 3 artikel atau sebesar 7\% dan variabel lain masing-masing memiliki persentase $5 \%$ atau kurang.
Tabel 5 menunjukkan variabel dari penelitian yang mengambil topik konsekuensi atau dampak dari pergantian auditor. Dari 5 artikel, variabel kualitas audit dibahas paling banyak yaitu sebanyak 3 kali (21\%). Variabel lain yaitu audit tenure, opini audit, serta ukuran KAP dibahas masing-masing sebanyak 2 kali (14\%). Variabel lain dibahas sebanyak 1 kali $(7 \%)$.

Tabel 5

Klasifikasi Variabel Konsekuensi

\begin{tabular}{llll}
\hline No & Variabel & Jumlah & Persentase \\
\hline $\mathbf{1}$ & Audit tenure & 2 & $14 \%$ \\
\hline $\mathbf{2}$ & Earnings per share & 1 & $7 \%$ \\
\hline $\mathbf{3}$ & Independensi auditor & 1 & $7 \%$ \\
\hline $\mathbf{4}$ & Kualitas audit & 3 & $21 \%$ \\
\hline $\mathbf{5}$ & Opini audit & 2 & $14 \%$ \\
\hline $\mathbf{6}$ & Pergantian Manajemen & 1 & $7 \%$ \\
\hline $\mathbf{7}$ & Regulasi pergantian auditor & 1 & $7 \%$ \\
\hline $\mathbf{8}$ & Return on Assets & 1 & $7 \%$ \\
\hline $\mathbf{9}$ & Ukuran KAP & 2 & $14 \%$ \\
\hline & & 14 & \\
\hline
\end{tabular}



Tabel 6 menunjukkan variabel yang dibahas oleh artikel yang membahas topik anteseden dan konsekuensi. Terdapat 2 variabel yang ditunjukkan dalam tabel ini dan setiap variabel hanya dibahas oleh 1 artikel saja.

Tabel 6

Klasifikasi Variabel Anteseden \& Konsekuensi

\begin{tabular}{llll}
\hline No & Variabel & Jumlah & Persentase \\
\hline $\mathbf{1}$ & Regulasi pergantian auditor & 1 & $50 \%$ \\
\hline $\mathbf{2}$ & Kualitas audit & 1 & $50 \%$ \\
\hline & Total & 2 & \\
\hline
\end{tabular}

\section{Klasifikasi Artikel berdasarkan Metode Penelitian}

Berdasarkan metode penelitian yang dilakukan dalam penelitian tentang pergantian auditor, artikel diklasifikasikan menjadi 3 yaitu metode analytical, survey, dan literature review.

Tabel 7 menunjukkan klasifikasi artikel yang membahas mengenai pergantian auditor berdasarkan metode penelitian yang digunakan. Seperti dijelaskan sebelumnya bahwa metode penelitian dibagi menjadi 3 (analytical, survey, dan literature review). Tabel 7 menunjukkan bahwa sebagian besar artikel menggunakan metode analytical (94\%), hanya sebagian kecil artikel menggunakan metode survey $(6 \%)$ dan tidak ada artikel yang menggunakan metode literature review. Pada periode pertama terdapat 5 artikel yang menggunakan metode analytical, dan tidak ada penelitian yang menggunakan metode lain. Pada periode kedua terdapat 12 penelitian yang menggunakan metode analytical dan 1 penelitian yang menggunakan metode survey.

Tabel 7

Klasifikasi Artikel berdasarkan Metode Penelitian

\begin{tabular}{llllllll}
\hline No & $\begin{array}{l}\text { Metode } \\
\text { Penelitian }\end{array}$ & 2009 s/d 2018 & \multicolumn{2}{l}{$\mathbf{2 0 0 9}$ s/d 2013 } & 2013 s/d 2018 \\
\cline { 2 - 8 } & Jumlah & Persentase & Jumlah & Persentase & Jumlah & Persentase \\
\hline $\mathbf{1}$ & Analytical & 17 & $94 \%$ & 5 & $100 \%$ & 12 & $92 \%$ \\
\hline $\mathbf{2}$ & Survey & 1 & $6 \%$ & 0 & $0 \%$ & 1 & $8 \%$ \\
\hline $\mathbf{3}$ & Review & 0 & $0 \%$ & 0 & $0 \%$ & 0 & $0 \%$ \\
\hline & Total & 18 & & 5 & & 13 & \\
\hline
\end{tabular}

\section{Perbandingan Artikel dilihat dari Topik dan Metode Penelitian}

Tabel 8 menunjukkan karakteristik artikel berdasarkan Cross-tabulation antara topik dengan metode penelitian. Tabel ini menunjukkan bahwa metode penelitian analytical banyak dipakai oleh peneliti untuk meneliti topik anteseden, yaitu sebanyak 12 artikel, sedangkan terdapat 5 artikel yang menggunakan metode analytical dengan topik konsekuensi, dan 1 artikel anteseden dan konsekuensi yang menggunakan metode analytical. Metode survey digunakan untuk meneliti 1 artikel dengan topik konsekuensi. 
Tabel 8

Klasifikasi Artikel berdasarkan perbandingan Topik dan Metode Penelitian

\begin{tabular}{lllll}
\hline NO & METODE & TOPIK & & \\
\cline { 3 - 5 } & & Anteseden & Konsekuensi & Anteseden \& konsekuensi \\
\hline $\mathbf{1}$ & Analytical & 12 & 4 & 1 \\
\hline $\mathbf{2}$ & Survey & 0 & 1 & 0 \\
\hline $\mathbf{3}$ & Review & 0 & 0 & 0 \\
\hline & Total & 12 & 5 & 1 \\
\hline
\end{tabular}

Berdasarkan data yang telah didapatkan dapat dilihat bahwa variabel Pergantian Manajemen merupakan variabel yang paling banyak dibahas oleh artikelartikel terkait pergantian auditor. Dari banyak variabel yang dibahas dalam artikel-artikel diatas, kebanyakan variabel hanya dibahas satu atau dua kali, yang menunjukkan bahwa terdapat variasi yang cukup luas dalam pemilihan variabel untuk penelitian yang terkait dengan pergantian auditor.

Variabel-variabel yang masih sedikit dibahas dapat memberikan kesempatan kepada peneliti berikutnya yang akan membuat artikel mengenai pergantian auditor. Peneliti dapat meneliti variabel yang masih sedikit dibahas atau variabel-variabel baru yang berbeda dengan artikel-artikel yang telah ada. Sebagian besar karakteristik perusahaan belum banyak dibahas dalam artikel-artikel terkait pergantian auditor, memungkinkan untuk mengembangkan penelitian terkait variabel tersebut (Ambiguitas Peran Manajemen, Foreign Ownership, Gaya Kepemimpinan, Institutional Ownership, Kebutuhan Untuk Berkembang, Kepemilikan Publik, Kepuasan Gaji, Kesempatan Promosi, Komite Audit, Konflik Peran, Managerial Ownership, Pertumbuhan Perusahaan, Perubahan Pendapatan Perusahaan, Profitabilitas, Rentabilitas).

Kebanyakan artikel sampel menggunakan metode analytical, sementara metode survey memiliki jumlah yang sangat sedikit dan tidak ada artikel yang menggunakan metode review. Penelitianpenelitian berikutnya dapat mencoba menggunakan metode selain metode analytical sehingga terdapat kemungkinan akan menemukan temuan baru yang berbeda dengan penelitian-penelitian sebelumnya.

\section{KESIMPULAN DAN SARAN}

Dalam studi ini, peneliti menganalisis 18 artikel yang membahas mengenai pergantian auditor yang diterbitkan melalui berbagai jurnal nasional yang dapat diakses oleh peneliti secara online berdasarkan topik dan metode penelitian. Kebanyakan jurnal tidak menerbitkan banyak artikel yang terkait dengan pergantian auditor. Hanya jurnal Accounting Analysis Journal yang memiliki artikel terkait pergantian auditor dengan jumlah yang relatif lebih banyak dibandingkan jurnal lain.

Topik yang dibahas dalam kebanyakan artikel adalah topik anteseden, dimana 12 artikel (67\%) artikel membahas mengenai topik ini. Sedangkan topik konsekuensi hanya dibahas oleh 5 artikel (28\%) dan topik anteseden dan konsekuensi hanya dibahas oleh 1 artikel (6\%). Metode yang digunakan oleh sebagian besar artikel adalah metode analytical dimana 17 artikel (94\%) menggunakan metode ini. Sementara hanya 1 artikel (6\%) saja yang menggunakan metode survey, dan tidak ada artikel yang menggunakan metode literature review.

Dari 31 jurnal nasional level 1 sampai 4 terkait akuntansi yang ter indeks oleh Sinta2, dengan total jumlah artikel di 31 jurnal tersebut mencapai 4693 (Database sinta2), hanya terdapat 18 artikel yang 
membahas mengenai pergantian auditor atau hanya sekitar $0,38 \%$ dari total keseluruhan artikel. Dilihat dari perbandingan dengan jumlah keseluruhan jurnal, jumlah artikel mengenai pergantian auditor masih sangat sedikit. Hal ini dapat menjadi kesempatan bagi peneliti untuk mengembangkan pembahasan mengenai topik pergantian auditor ini.

Penelitian ini masih memiliki banyak keterbatasan diantaranya akses artikel yang masih sangat terbatas dan tidak dapat mencakup setiap artikel yang membahas mengenai pergantian auditor yang diterbitkan oleh setiap jurnal nasional terutama yang tidak bias diakses secara online. Penelitian selanjutnya dapat mengembangkan jumlah artikel yang diteliti serta menambahkan sumber jurnal lain. Keterbatasan lain adalah analisa data yang masih sederhana dan kurang mendalam terkait topik dan variabel dari artikel-artikel yang diteliti. Penelitian selanjutnya dapat melakukan analisa yang lebih mendalam terhadap setiap bagian dari artikel yang diteliti.

\section{DAFTAR PUSTAKA}

Adhiputra, M. W. (2015). Pengaruh Penerbitan Opini Going Concern pada Pergantian Auditor pada Perusahaan yang Terdaftar pada Bursa Efek Indonesia. Jurnal Dinamika Akuntansi, 7(1), 22-36.

Aprillia, E. (2013). Analisis Faktor-Faktor Yang Mempengaruhi Auditor Switching. Accounting Analysis Journal, 2(2), 1-9. https://doi.org/ISSN 2252-6765

Budisantoso, T., Rahmawati, Bandi, \& Probohudono, A. N. (2017). Determinants of Downward Auditor Switching. Jurnal Akuntansi Multiparadigma, 8(3), 444-457.

Fadil, Y., \& Yulianto, A. (2017). The Determinant of KAP Changes with Audit Committee Quality as A Moderating Variable. Accounting Analysis Journal, 6(1), 81-93.
Fitriany, Utama, S., Martani, D., \& Rosietta, H. (2015). Pengaruh Tenure, Rotasi dan Spesialisasi Kantor Akuntan Publik (KAP) Terhadap Kualitas Audit: Perbandingan Sebelum dan Sesudah Regulasi Rotasi KAP di Indonesia. Jurnal Akuntansi Dan Keuangan, 17(1), 1227. https://doi.org/10.9744/jak.17.1.1227

Hesford, J. W., Lee, S., Van der Stede, W. A., \& Young, S. M. (2007). Management accounting: a bibliographic study. Handbook of management accounting research. Elsevier Ltd.

Irianto, G., Novianti, N., \& Wulandari, P. P. (2014). "Kamuflase" alam Praktik Rotasi Auditor. Jurnal Akuntansi Multiparadigma, 5(3), 393-408.

Ismanto, J., \& Manda, D. L. (2018). Pengaruh Financial Distress, Pergantian Manajemen dan Ukuran KAP Terhadap Auditor Switching. Media Riset Akuntansi, Auditing \& Informasi, 18(2), 205-224. https://doi.org/http://dx.doi.org/10.25 105/mraai.v18i2.3069

Karina, F. L., Kholmi, M., \& Harventy, G. (2014). Pengaruh Opini Going Concern, Pergantian Manajemen dan Ekspansi Internal Terhadap Auditor Switching Secara Voluntary, 4(1), 555-562.

Maryani, S., Respati, N. W., \& Safrida, L. (2016). Pengaruh Financial Distress, Pertumbuhan Perusahaan, Rentabilitas, Ukuran Kap, dan Ukuran Perusahaan Terhadap Pergantian Auditor, 6(2), 873-884.

Nurcahyo, D. D., \& Anisykurlillah, I. (2017). Analysis of The Influence of The Size of KAP, Management Turnover and Size of Company toward Auditor Switching (An Empirical Study on Manufacturing Companies Registered in Indonesian Stock Exchange Year 2011-2015). 
Accounting Analysis Journal, 6(1), 128136.

Nurhayati, S., \& Prastiti, S. D. (2015). Pengaruh Rotasi Kap, Audittenure, dan Reputasi Kap Terhadap Kualitas Audit Pada Perusahaan Manufaktur. Jurnal Akuntansi Akrual, 3(2), 165174.

Paputungan, R. D., \& Kaluge, D. (2018). Pengaruh Masa Perikatan Audit, Rotasi Audit dan Ukuran Kantor Akuntan Publik Terhadap Kualitas Audit. Jurnal Reviu Akuntansi Dan Keuangan, 8(1), 93-103. https://doi.org/10.22219/jrak.v8i1.29

Permatasari, D. (2013). Faktor-Faktor yang Mempengaruhi Keinginan Berpindah Auditor (Studi Empiris pada Kantor Akuntan Publik di Jawa Tengah dan Daerah Istimewa Yogyakarta). Jurnal Dinamika Akuntansi, 5(2), 121-134. Retrieved from

http://journal.unnes.ac.id/nju/index.p $\mathrm{hp} / \mathrm{jda}$

Prastiwi, A., \& Wilsya, F. (2009). FaktorFaktor yang Mempengaruhi Pergantian Auditor: Studi Empiris Perusahaan Publik di Indonesia. Jurnal Dinamika Akuntansi, 1(1), 62-75.

Rokhmatun, R. N., \& Suryarini, T. (2016). Empirical Study of Public Accounting Firm Changes on The Company after The Emergence of The Public Accounting Firm Regulatory Liability. Accounting Analysis Journal, 5(4), 337-343.

Siregar, S. V., Fitriany, Wibowo, A., \& Anggraita, V. (2011). Rotasi dan Kualitas Audit: Evaluasi Atas Kebijakan Menteri Keuangan KMK No. 423/KMK.6/2002 Tentang Jasa Akuntan Publik. Jurnal Akuntansi Dan Keuangan Indonesia, 8(1), 1-20. Sumadi, K. (2011). Mengapa Perusahaan Melakukan Auditor Switch? Jurnal Ilmiah Akuntansi Dan Bisnis, 6(1), 111.
Wahyuningsih, N., \& Suryanawa, I. K. (2012). Analisis Pengaruh Opini Audit Going Concern dan Pergantian Manajemen Pada Auditor Switching. Jurnal Ilmiah Akuntansi Dan Bisnis, 7(1), 1-20.

Werastuti, D. N. S. (2015). Analisis Prediksi Potensi Risiko Fraudulent Financial Statement Melalui Personal Financial Need dan Auditor Switching. Jurnal Ilmiah Akuntansi Dan Bisnis, 10(1), 37-44. 